\title{
Evaluasi Pengadaan Obat Secara E-Purchasing Berdasarkan E- Katalog Menggunakan Dana Kapitasi Jaminan Kesehatan Nasional Di Puskesmas Sekampung Kabupaten Lampung Timur
}

\section{Evaluation of Drug Procurement by E-Purchasing Based on E-Catalog Using the National Health Insurance Capitation Fund At the Sekampung Puskesmas, East Lampung Regency}

\author{
Restina Saptarisa', Dina Dwi Nuryani ${ }^{2}$, Agung Aji Perdana \\ ${ }^{1}$ Puskesmas Sekampung, Lampung Timur, Indonesia \\ ${ }^{2}$ Fakultas Kesehatan Masyarakat Universitas Malahayati, Bandar Lampung, \\ Lampung, Indonesia \\ *korespondensi Penulis: restinasapta@yahoo.com
}

Penyerahan: 29-07-2020, Perbaikan: 23-03-2020, Diterima: 02-07-2020

\begin{abstract}
The problems that occur in Sekampung Health Center are the number of drug realization that is not in accordance with the proposed Drug Needs Plan in 2017 where only 38.7\% was realized and in 2018 only 26.3\% were realized. This disrupted drug fulfillment services to the community which impacted on patients due to drug vacancy. The gap between the planning and realization of the procurement of the drug causes researchers to feel interested in conducting research with the aim of evaluating the procurement process of e-purchasing based on e-catalog using the National Health Insurance capitation fund at Puskesmas Sekampung, East Lampung Regency. This research method uses a qualitative approach, with research informants including Goods Procurement officials, Commitment Making Officers, and Pharmacists and triangulation of sources in the form of documenting drug management. Data analysis uses content analysis. The results of this study indicate that the causes of the gap between the number of drugs obtained compared with the drugs that have been submitted through the RKO include: 1) the process of issuing SK for each party involved in the e-purchasing process that is too long, 2) the process of approval is quite long , 3) the time of massaging is done at the end of the year and at the same time by all puskesmas which makes the distributor unable to fulfill all incoming orders relating to the stock of goods that have started to run out. This research suggests that the East Lampung Regency Health Office can accelerate the process of issuing SK for parties related to the e-purchasing process.
\end{abstract}

Keywords: Drug Procurement, E-Purchasing, E-Catalog.

\section{ABSTRAK}

Permasalahan yang terjadi di Puskesmas Sekampung yaitu jumlah realisasi obat yang tidak sesuai dengan Rencana Kebutuhan Obat yang telah diajukan dimana pada tahun 2017 hanya terealisasi sebanyak 38,7\% dan tahun 2018 hanya terealisasi sebanyak $26,3 \%$. Hal ini berdampak pada pasien karena akan terjadi kekosongan obat. Kesenjangan antara perencanaan dan realisasi pengadaan obat tersebut yang menyebabkan peneliti merasa tertarik melakukan penelitian dengan tujuan mengevaluasi proses pengadaan obat secara e-purchasing berdasarkan e-katalog menggunakan dana kapitasi Jaminan Kesehatan Nasional di Puskesmas Sekampung Kabupaten Lampung Timur. Metode penelitian ini menggunakan pendekatan kualitatif, dengan informan penelitian meliputi pejabat Pengadaan Barang, Pejabat Pembuat Komitmen, dan Apoteker dan triangulasi sumber berupa dokumentasi pengadana obat. Analisis data menggunakan analisis isi.Hasil penelitian ini menunjukkan bahwa penyebab terjadinya kesenjangan antara jumlah obat yang didapatkan dibandingkan dengan obat yang telah diajukan melalui RKO diantranya yaitu: 1) proses pengeluaran Surat Keputusan untuk

Jurnal Dunia Kesmas, Vol. 9 No. 2, Maret 2020, hal. 215 - 222

ISSN 2301-6604 (Print), ISSN 2549-3485 (Online)

http://ejurnalmalahayati.ac.id/index.php/duniakesmas/index 
setiap pihak yang terlibat dalam proses e-purchasing yang terlalu lama, 2) proses approve yang cukup panjang, 3) waktu pemasanan yang dilakukan diakhir tahun dan bersamaan oleh seluruh puskesmas yang membuat distributor tidak dapat memenuhi semua pesanan yang masuk berkaitan dengan stock barang yang sudah mulai habis. Penelitian ini menyarankan agar pihak Dinas Kesehatan Kabupaten Lampung Timur untuk dapat mempercepat proses pengeluaran Surat Keputusan tugas bagi pihak-pihak yang terkait dengan proses e-purchasing.

Kata kunci: Pengadaan Obat, E-Purchasing, E-Katalog.

\section{PENDAHULUAN}

Program Jaminan Kesehatan Nasional yang diluncurkan pada awal 2014 merupakan program jaminan perlindungan kesehatan yang ditujukan untuk seluruh rakyat Indonesia. Pemerintah bertanggung jawab atas pelaksanaan jaminan kesehatan masyarakat melalui suatu badan penyelenggara jaminan sosial. Sebagaimana diatur dalam UndangUndang Nomor 24 Tahun 2011 tentang Badan Penyelenggara Jaminan Sosial (BPJS) menetapkan Badan Penyelenggara Jaminan Sosial (BPJS) Kesehatan sebagai badan penyelenggara program jaminan kesehatan tersebut. Dan fasilitas kesehatan yang menyelenggarakan pelayanan kesehatan untuk peserta JKN adalah Fasilitas Kesehatan Tingkat Pertama (FKTP) salah satunya adalah Puskesmas (Permenkes No. 28/2014).

Pengelolaan Obat dan Bahan Medis Habis Pakai merupakan salah satu kegiatan pelayanan kefarmasian, yang dimulai dari perencanaan, permintaan, penerimaan, pendistribusian, penyimpanan, pengendalian, pencatatan dan pelaporan serta pemantauan dan evaluasi. Tujuannya adalah untuk menjamin kelangsungan ketersediaan dan keterjangkauan Obat dan Bahan Medis Habis Pakai yang efisien, efektif dan rasional, meningkatkan kompetensi/ kemampuan tenaga kefarmasian, mewujudkan sistem informasi manajemen, dan melaksanakan pengendalian mutu pelayanan (Permenkes No 30 Tahun 2014).

Pada

merupakan sistem manajemen informasi yang menghubungkan antara pemerintah (LKPP, Kemenkes, Badan POM), produsen (pabrik obat, distributor), dan pengguna (rumah sakit, puskesmas) dalam proses pengadaan obat JKN. Berbasis teknologi informasi, sistem e-katalog bertujuan memberikan kenyamanan, efisiensi, harga yang wajar, dan informasi obat baru; menempatkan pembeli pada efisiensi tertinggi (Ketikidis et al., 2010). Dengan sistem online yang transparan tersebut diharapkan rumah sakit dan puskesmas dapat melakukan pengadaan obat JKN secara mudah.

E-purchasing merupakan tata cara pembelian barang sesudah sistem Katalog Elektronik ( $E-$ Catalogue) terbangun. Dengan telah terbangunnya sistem Katalog Elektronik (E-Catalogue) obat, maka seluruh Satuan Kerja di bidang kesehatan baik pusat maupun daerah dan FKTP atau FKRTL dalam pengadaan obat baik untuk program Jaminan Kesehatan Nasional maupun program kesehatan lainnya tidak perlu melakukan proses pelelangan, namun dapat langsung memanfaatkan sistem Katalog Elektronik (E-Catalog) obat dengan prosedur E-Purchasing.

Salah satu metode pengadaan berbasis elektronik (eprocurement).E-procurement 
merupakan pemanfaatan sistem teknologi informasi dalam otomatisasi proses pengadaan (Bottani dan Rizzi, 2005). Eprocurement telah dilaksanakan diberbagai negara, seperti yang telah diteliti oleh Gunasekaran et al. (2008) di Hongkong, Teo et al (2009) di Singapura, Eei et al (2012) di Malaysia. Implementasi sistem eprocurement pada sektor kesehatan telah diteliti oleh Ketikidis et al (2010).

E-catalogue obat adalah system informasi elektronik yang memuat daftar, jenis, spesifikasi teknis, dan harga obat dari berbagai penyedia obat. Produk penyedia dan informasi harga yang ditampilkan melalui katalog elektronik bisa diakses oleh pembeli melalui web. Pada proses pembelian keputusan menjadi lebih mudah. Pengaturan pengadaan obat berdasarkan Katalog Elektronik (ECatalogue) bertujuan untuk menjamin transparansi/ keterbukaan, efektifitas danefisiensi proses pengadaan obat dalam rangka memenuhi kebutuhan pelayanan kesehatan yang hasilnya dapat dipertanggungjawabkan (Permenkes No. 63 Tahun 2014).

Permasalahan yang terjadi di Puskesmas Sekampung yaitu jumlah realisasi obat yang tidak sesuai dengan Rencana Kebutuhan Obat yang telah diajukan melalui Rencana Kebutuhan Obat (RKO) dimana pada tahun 2017 dari 49 item obat yang diajukan hanya terealisasi sebanyak 19 item $(38,7 \%)$ dan untuk tahun 2018 dari 32 item obat yang diajukan hanya terealisasi sebanyak 10 item (26,3\%). Kondisi yang terjadi di beberapa puskesmas lain yaitu Puskesmas Batanghari untuk tahun 2017 dari 33 item yang diajukanterealiasi sebanyak 12 item $(26,37 \%)$ dan untuk tahun 2018 dari 26 item yang diajukanterealiasi 12 item $(46,2 \%)$, sedangkan untuk
Puskesmas SukarajaNuban untuk tahun 2017dari 45 item yang diajukanterealisasi sebanyak 20 item (44,4\%) dan untuk tahun 2018 dari 43 item obat yang diajukanterealisasi 22 item $(51,16 \%)$. Hal tersebut tentu saja dapat menyebabkan terganggunya pelayanan pemenuhan obat kepada masyarakat yang berdampak pada pasien karena kekosongan obat.

\section{METODE PENELITIAN}

Penelitian ini menggunakan metode penelitian kualitatif. Pendekatan yang dilakukan yaitu dengan metode penelitian evaluasi sumatif. Peneliti akan menggunakan informan untuk memperoleh berbagai informasi yang diperlukan selama proses penelitian. Informan kunci (key informan) dalam penelitian ini adalah Pejabat Pengadaan barang, Informan sumber: Apoteker dan Pejabat Pembuat Komitmen.Instrumen penelitian adalah pedoman wawancara mendalam. Data kualitatif analisisnya dilakukan dengan analisis isi (content analysis). Analisis data melalui tahap reduksi data, penyajian data dan penarikan kesimpulan.

\section{HASIL DAN PEMBAHASAN}

\section{Input}

Proses e-purchasing yang meliputi pihak yang terkait dengan proses $e$ purchasing dari pihak puskesmas terdiri dari Kepala UPTD Puskemas dan Pengelola Obat dalam penyusunan RKO, Tim perencanaan obat sebagai verifikator RKO, yang selanjutnya bersama dengan Kuasa Pengguna Anggaran (KPA), Pejabat Pembuat Komitmen selaku penanggung jawab pengadaan, dilanjutkan dengan proses verifikasi oleh Apoteker, dan dilanjutkan proses e-purchasing oleh Pejabatan Pengadaan (PP). Berkaitan dengan 
dasar yang digunakan oleh pihak puskesmas dalam melakukan proses e-purchasing mengacu pada Perpres No 16 Tahun 2018 tentang Pengadaan Barang dan Jasa, (Fornas) dan (DOEN).

Komponen yang dimasukkan dalam Rencana Kebutuhan Obat diantarnya yaitu item obat, jumlah satuan obat (satuan atau kemasan obatnya), jumlah satuan dalam rupiah, penyedia barang, nama obat, kemudian stok terakhir (stok di periode tahun sebelumnya), kemudian jumlah kebutuhannya berapa, dikurangi dengan stok tahun sebelumnya dan beberapa lampiran mengenai Surat Keputusan (SK) untuk PPK, Pejabat Pengadaan dan Apoteker yang disahkan oleh Kepala Dinas Kesehatan. Berkenaaan dengan mekanisme yang bisa digunakan sesuai dengan ketentuan yang ada di permenkes dan Fornas yaitu dilakukan langsung oleh pejabat pengadaan karena umunya nilai pengadaan untuk Puskesmas masih dibawah 200 juta rupiah.

Berdasarkan keseluruhan uraian pada input tersebut terlihat bahwa dalam proses input proses $e$ purchasing sudah sesuai dengan prosedur dan mekanisme yang ada dalam Perpres No 16 Tahun 2018 Tentang Pengadaan Barang dan Jasa dan (Fornas) dan (DOEN) dimana dalam proses pengadaan barang dan jasa dilakukan oleh Pengguna Anggaran yang selanjutnya disingkat PA adalah pejabat pemegang kewenangan penggunaan anggaran (Pasal 1ayat 7), Pejabat Pembuat Komitmen yang selanjutnya disingkat PPK adalah pejabat yang diberi kewenangan oleh PA/KPA untuk mengambil keputusan dan/atau melakukan tindakan yang dapat mengakibatkan pengeluaran anggaran belanja (Pasal 1 ayat 10), Pejabat Pengadaan adalah pejabat administrasi/pejabat fungsional/personel yang bertugas melaksanakan Pengadaan Langsung, Penunjukan Langsung, dan/atau epurchasing (Pasal 1 ayat 13), Pejabat Pemeriksa Hasil Pekerjaan yang selanjutnya disingkat PjPHP adalah pejabat administrasi/ pejabat fungsional/personel yang bertugas memeriksa administrasi hasil pekerjaan Pengadaan Barang/Jasa (pasal 1 ayat 14), dan Penyedia Barang/Jasa Pemerintah yang selanjutnya disebut Penyedia adalah Pelaku Usaha yang menyediakan barang/jasa berdasarkan kontrak (pasal 1 ayat 28).

Mengenai komponen yang ada dalam RKO juga sudah sesuai dengan peraturanyang ada dimana mencantumkan item obat, jumlah satuan obat (satuan atau kemasan obatnya), jumlah satuan dalam rupiah, penyedia barang nama obat, kemudian stok terakhir (stok di periode tahun sebelumnya), kemudian jumlah kebutuhannya berapa, dikurangi dengan stok tahun sebelumnya dimana berdasarkan penjelasan Peraturan Presiden Nomor 54 Tahun 2010 sebagaimana telah diubah dengan Peraturan Presiden Nomor 70 Tahun 2012, obat termasuk dalam kriteria barang/jasa khusus karena jenis, jumlah dan harganya telah ditetapkan oleh Menteri Kesehatan sehingga dapat dilakukan pengadaan melalui penunjukan langsung serta Surat Edaran Menteri Kesehatan Nomor KF/MENKES/167/III/2014 tentang Pengadaan Obat Berdasarkan Katalog Elektronik, seluruh satuan kerja di bidang kesehatan baik pusat maupundaerah dan Fasilitas Kesehatan Tingkat Pertama maupun Fasilitas Kesehatan Rujukan Tingkat Lanjutan yang bekerja sama dengan Badan Penyelenggara Jaminan Sosial (BPJS) Kesehatan dalam pengadaan obat baik untuk Program Jaminan Kesehatan Nasional maupun program 
kesehatan lainnya dihimbau agar pengadaan obat dilaksanakan berdasarkan Katalog eleketronik (ekatalog) obat dengan menggunakan metode pembelian secara elektronik (e-purchasing). Hal ini dimaksudkan untuk menjamin ketersediaan dan pemerataan obat yang aman, bermutu dan berkhasiat untuk memenuhi kebutuhan pelayanan kesehatan, yang pengadaannya dilaksanakan secara transparan, efektif, efisien serta hasilnya dapat dipertanggungjawabkan.

Berdasarkan hasil penelitian dan teori yang ada tersebut maka diperoleh gambaran input dari proses e-purchasing jika dikaitkan dengan permasalahan dalam penelitian ini yaitu tidak terpenuhinya jumlah kebutuhan obat seusuai dengan RKO yang ada, maka permaslaahan tersebut tidak tergambar atau disebabkan oleh aspek input dari proses e-purchasing karena sudah sesuai dengan mekanisme yang ada. Hasil ini memiliki kesesuaian dengan penelitian (Adyaksa, 2016) di Dinas Kesehatan Kota Denpasar serta empat Puskesmas di Kota Denpasar dengan hasil ketersediaan input dari proses pengadaan obat berdasarkan e-catalogue dari segi pendanaan mencukupi, telah dilengkapi juknis pelaksanaan.

Dari hasil yang sudah diperoleh dari segi input tersebut tidak tergambar mengenai faktor terkait dengan permasalahan dalam penelitian ini yaitu tidak terpenuhinya jumlah kebutuhan obat seusuai dengan RKO.

\section{Proses}

Proses dari penyusunan RKO dilakukan oleh PPK, Pejabat Pengadaan, KPA, dan apoteker dengan urutan kerja sebagai berikut proses awal yaitu pembentukan SK oleh kepala dinas tim atau perangkat pengadaan, didalamnya ada PPK,
Pejabat pengadaan, KPA, apoteker. Karena keterbatasan SDM yang mempunyai sertifikasi pengadaan barang, jadi beberapa puskesmas dibawahi oleh satu PPK, Pejabat pengadaan barang dan apoteker, dimana SK penunjukkan para petugas tersebut dikeluarkan biasanya pada bulan September atau Oktober atau November sehingga proses kerja ketiga petugas tersebut juga bisa dimulai pada bulan-bulan tersebut. Proses tersebut berlanjut ke alur e-purchasing selanjutnya yaitu setelah RKA diverifikasi dan diserahkan ke PPK selanjutnya dilanjutkan kepada Pejabat Pengadaan untuk dilakukan proses pemesanan melalui e-purchasing dengan menggunakan akun yang tersedia. Keterangan tambaahn yang diperoleh bahwa proses ini dapat langsung dilakukan oleh Pejabat Pengadaan untuk nilai pemesanan dibawah 200 juta, jika lebih dari jumlah tersebut maka dilakukan oleh Pejabat Pembuat Komitmen. Setelah proses upload pemesanan barang melalaui e-purchasing tinggal menunggu persetujuan, jika disetujui berarti proses dilanjutkan. Kalau tidak disetujui dapat dilakukan pemesanan alternatif lain untuk pengadaannya menggunakan misalnya pengadaan langsung non e-katalog. Melalui proses e-purchasing tersebut dihasilkan beberapa dokumen diantarnaya yaitu surat pesanan dari Aplikasi LPSE, surat perjanjian/kontrak antara PPK dan Distributor.

Berkaitan dengan alur proses pada verifikasi oleh apoteker dengan pejabaran sebagai berikut, setelah RKO diterima oleh apoteker kemudian diperiksa kebutuhannya berapa di sesuaikan dengan anggaran yang ada, kemudian dilakukan desk data RKO dengan masing-masing puskesmas

Jurnal Dunia Kesmas, Vol. 9 No. 2, Maret 2020, hal. 215 - 222

ISSN 2301-6604 (Print), ISSN 2549-3485 (Online)

http://ejurnalmalahayati.ac.id/index.php/duniakesmas/index 
melibatkan dokter, pengelola obat, kepala puskesmas atau bisa diwakili oleh pengelola obat saja. Jika obatnya sudah dicukupi oleh kabupaten, maka bisa saja pengajuan obat tersebut di tolak item-item obatnya, kalau obatnya jumlahnya terbatas di dinas, maka itu bisa disetujui. Setelah RKO dierifikasi dan disetujui oleh apoteker diajukan kembali ke bendahara puskesmas, kemudian lanjut diteruskan ke pejabat pengadaan melalui PPK, melalui persetujuan PPK sampai di pejabat pengadaan kemudian di upload di e-purchasing atau di e-katalog obat. Selanjutnya berkaitan dengan permasalahan waktu dari prose e-purchasing sampai dengan obat diterima oleh pihak puskesmas diperoleh keterangan bahwa selama ini umumnya berlangsung selama 3 bulan. Berkaitan dengan lamanya waktu diterimanya barang tersebut diperoleh gambaran mengenai prosesnya yaitu sejak dari proses upload pesanan yang selanjutnya disetujui oleh pihak distributor maka langkah selanjutnya adalah kembali lagi butuh approve dari pejabata pengadaan dan PPK setelah itu baru ke penyedia lagi baru proses pengiriman barang. Alur ini yang terkadang juga menambah waktu dari proses e-purchasing dimana proses approve yang dilakukan oleh PP dan PPK tidak segera dilakukan dikarenakan mereka yang tidak membuka akun e-purchasing setiap saat sehingga terkadang membutuhkan waktu beberapa hari. Selain itu pemasalahan yang terungkap dari hari wawancara tersebut diantaranya yaitu pihak penyedia yang terlalu lama mengirimkan barang dikarenakan alasan mereka harus mengkonfirmasi mengenai ketersediaan barang di distributor daerah masing-masing sesuai dengan daerah puskesmas yang memesan. Meskipun pihak puskesmas terkadang menguhubungi pihak penyedia namun tetap saja proses pengiriman yang lambat serta jumlah yang dapat dipenuhi tidak sesuai dengan jumlah pemesanan. Pihak penyedia selama ini beralasan mengenai keterlambatan serta jumlah pengiriman yang tidak sesuai dengan pemesanan tersebut disebabkan proses pemesanaan yang sudah dilakukan diakhir tahun serta berbarengan dengan seluruh puskesmas yang ada sehingga stock sudah mulai menipis dan tidak dapat dipenuhi semua kebutuhan dari tiap puskesmas.

Berdasarkan hasil yang diperoleh mengenai proses dari e-purchasing tersebut diperoleh gambaran bahwa alur yang dilakukan oleh setiap puskesmas sudah sesuai dengan prosedur yang ada dimana proses pemesanan melalui e-katalog dilakukan sesuai dengan mekanisme yang ada sesuai Perpres Nomor 70 Tahun 2012 dan Permenkes Nomor 63 Tahun 2014 tentang Pengadaan Obat Berdasarkan Katalog elektronik (E-catalogue) dengan urutan 1) Pokja ULP/Pejabat Pengadaan membuat permintaan pembelian obat berdasarkan pengelompokan penyedia melalui aplikasi epurchasing, sesuai daftar rencana pengadaan obat (Form 2) dari PPK, 2) Pokja ULP/Pejabat Pengadaan kemudian mengirimkan permintaan pembelian obat kepada penyedia obat/industri farmasi yang terdaftar pada e-katalog. 3) Penyedia obat yang telah menerima permintaan pembelian obat dari Pokja/Pejabat Pengadaan memberikan persetujuan atau penolakan atas permintaan pembelian obat melalui e-purchasing dan apabila menyetujui, menunjuk distributor yang sudah ditentukan dari semula dan ditampilkan dalam e-katalog obat. Apabila menolak, penyedia obat/PBF harus

Jurnal Dunia Kesmas, Vol. 9 No. 2, Maret 2020, hal. 215 - 222

ISSN 2301-6604 (Print), ISSN 2549-3485 (Online)

http://ejurnalmalahayati.ac.id/index.php/duniakesmas/index 
menyampaikan alasan penolakan, 4) Persetujuan penyedia obat/Industri Farmasi kemudian diteruskan oleh Pokja ULP/Pejabat Pengadaan kepada PPK untuk ditindaklanjuti. Dalam hal permintaan pembelian obat mengalami penolakan dari penyedia obat/Industri Farmasi, maka ULP melakukan metode pengadaan lainnya sesuai Peraturan Presiden Nomor 54 Tahun 2010 tentang Pengadaan Barang/Jasa Pemerintah sebagaimana telah diubah terakhir dengan Peraturan Presiden Nomor 70 Tahun 2012, 5) Sesudah persetujuan oleh penyedia, Pokja ULP/Pejabat Pengadaan memberikan persetujuan/penolakan dan apabila menyetujui, meneruskan kepada PPK melalui aplikasi epurchasing, 6) PPK selanjutnya melakukan perjanjian/kontrak jual beli terhadap obat yang telah disetujui dengan distributor/PBF yang ditunjuk oleh penyedia obat/ Industri Farmasi dan7) Distributor/PBF melaksanakan penyediaan obat sesuai dengan isi perjanjian/kontrak jual beli.

Berdasarkan hasil penelitian dan teori serta dokumentasi yang ada maka diperoleh gambaran proses epurchasing jika dikaitkan dengan permasalahan dalam penelitian mengenai tidak terpenuhinya julah kebutuhan obat yang dipesai sesuai dengan RKO disebabkan oleh beberapa hal diantarnaya yaitu: 1) proses pengeluaran SK untuk setiap pihak yang terlibat dalam proses pengadaan seperti SK Pejabat pengadaan, SK Pejabat pembuat Komitmen dan SK Apoteker yang dikeluarkan oleh dinas pada waktu yang lama biasanya pada triwulan ketiga akhir tahun bulan oktober sehingga mereka baru dapat mulai bekerja sesuai dengan tanggal SK dikeluarkan, dimana hal ini membuat proses e-purchasing menjadi lama, 2) proses approve yang cukup panjang dimana proses pengiriman barang dapat dilakukan setelah adanya approve dari pejabat pengadaan, Pejabat Pembuat Komitmen dimana kedua pejabat tersebut juga terkadang tidak langsung membuka akun untuk melakukan approve dimana hal tersebut bisanya berlangsung lama dan menghambar proses pengiriman barang oleh distributor, 3) waktu pemasanan yang dilakukan diakhir tahun dan secara bersamaan oleh seluruh puskesmas membuat distributor tidak dapat memenuhi semua pesanan yang masuk berkaitan dengan stock barang yang sudah mulai habis serta pengiriman barang oleh distributor yang ada didaerah sehingga menambah waktu untuk menunggu konfirmasi mengenai ketersedian barang di distributor daerah kepada penyedia di pusat.

Hasil peneltiian ini memiliki kesesuaian dengan hasil penelitian oleh (Kusmini, 2016) di 35 Dinas Kesehatan Kabupaten dan Kota di Jawa Tengah dengan hasil 45,3\% obat indikator diadakan melalui mekanisme e-purchasing oleh 97,3\% Dinas Kesehatan Kabupaten dan Kota. Realisasi obat yang tidak sesuai rencana sebesar 23,9\%, yang menunjukkan adanya hambatan pelaksanaan e-purchasing yaitu ketidakmampuan suplai oleh distributor. Penelitian (Dwiaji,dkk., 2016) yang melakukan evaluasi terhadap e-Order menurut kategorisasi obat, yaitu generik (OGB) dan dengan merek dagang (OMD), pada data e-Catalogue 20142015 dengan hasil adanya kesenjangan antara RKO dan eOrder. Menurut data kualitatif terutama berakar dari penetapan RKO dan HPS serta penayangan eCatalogue yang tidak memberikan cukup waktu bagi pemenang lelang untuk mempersiapkan obat dalam 
jumlah yang sesuai dengan komitmen, pada saat dibutuhkan oleh fasilitas kesehatan. Penelitian (Adyaksa, 2016) di Dinas Kesehatan Kota Denpasar serta empat Puskesmas di Kota Denpasar dengan hasil ketersediaan input dari proses pengadaan obat berdasarkan ECatalogue dari segi pendanaan mencukupi, telah dilengkapi juknis pelaksanaan, SDM masih kurang dan sasaran belum mencapai 100\% Puskesmas di Kota Denpasar. Proses perencanaan kebutuhan obat lebih sistematis dibanding sebelumnya dan sudah sesuai dengan Peraturan Menteri Kesehatan No. 63 Tahun 2014. Pemesanan dan perjanjian kontrak yang dilakukan telah sesuai dengan PMK. Distribusi obat pernah mengalami keterlambatan dan realisasi obat tidak mencapai $100 \%$. Faktor penghambatnya adalah tim pengadaan yang dibentuk kurang efektif, kerja sama dengan banyak rekanan dan gangguan sistem yang sering terjadi dari server pusat. Secara keseluruhan implementasi pengadaan obat berdasarkan $E$ Catalogue telah berjalan dengan cukup baik, namun masih ditemukan berbagai permasalahan dari segi input proses dan output. Dari hasil yang sudah diperoleh dari segi proses tersebut tergambar mengenai faktor terkait dengan permasalahan dalam penelitian ini mengenai tidak terpenuhinya jumlah kebutuhan obat sesuai dengan RKO yaitu: 1) proses pengeluaran SK untuk setiap pihak yang terlibat dalam proses pengadaan yang lama sehingga mereka baru dapat mulai bekerja sesuai dengan tanggal SK dikeluarkan, 2) proses approve yang cukup panjang serta pihak-pihak berkaitan tidak melakukan melakukan approve sesegera mungkin, 3) waktu pelksanaan pemasanan yang dilakukan diakhir tahun dan secara bersamaan oleh seluruh puskesmas membuat distributor tidak dapat memenuhi semua pesanan yang masuk berkaitan dengan stock barang yang sudah mulai habis.

\section{Output}

Tergambar dari pihak apoteker dimana masih terdapat kendala adanya RKO yang diajukan oleh pihak puskesmas terkadang harus ada yang direvisi karena pihak puskesmas yang mengajukan obatobat untuk Fasilitas Kesehatan Rujukan Tingkat Lanjut sedangkan puskesmas sendiri adalah Fasilitas Kesehatan Tingkat Pertama, sehingganya banyak obat-obat yang memang ada di Fasilitas Kesehatan Rujukan Tingkat Lanjut bisa dipenuhi di FKTP, tidak harus mengadakan obat untuk faskes lanjutan. Mengenai laporan hasil dari proses epurchasing dibuat dalam bentuk surat pertanggung jawaban yang diserahkan kepada KPA, PPK dan distributor. Berdasarkan hasil yang diperoleh dari segi output dari pelaksanaan e-purchasing diperoleh hasil dimana jumlah obat yang diterima tidak sesuai dengan jumlah yang telah dipesan, hal ini tidak sesuai dengan ketentuan yang ada dimana seharusnya pihak penyedia mengirimkan barang sesuai dengan jumlah yang telah dipesan, namun kondisi tersebut tidak dapat ditindak lanjuti dikarenakan hal tersebut disebabkan oleh banyak faktor yang juga terkait dari pihak pemesan barang yang melakukan pesanan diakhir tahun.

Hasil ini memiliki kesesuaian dengan penelitian yang dilakukan oleh (Kusmini, 2016) pada 35 Dinas Kesehatan Kabupaten dan Kota di Jawa Tengah dengan hasil 45,3\% obat indikator diadakan melalui mekanisme e-purchasingoleh 97,3\% Dinas Kesehatan Kabupaten dan Kota. Realisasi obat yang tidak

Jurnal Dunia Kesmas, Vol. 9 No. 2, Maret 2020, hal. 215 - 222

ISSN 2301-6604 (Print), ISSN 2549-3485 (Online)

http://ejurnalmalahayati.ac.id/index.php/duniakesmas/index 
sesuai rencana sebesar 23,9\%, yang menunjukkan adanya hambatan pelaksanaan e-purchasing yaitu ketidakmampuan suplai oleh distributor. Penelitian (Adyaksa, 2016) di Dinas Kesehatan Kota Denpasar serta empat Puskesmas di Kota Denpasar dengan hasil ketersediaan input dari proses pengadaan obat berdasarkan $E$ Catalogue dari segi pendanaan mencukupi, telah dilengkapi juknis pelaksanaan, SDM masih kurang dan sasaran belum mencapai 100\% Puskesmas di Kota Denpasar.

Berdasarkan hasil analisis terhadap output tersebut tergambar permasalahan yang diangkat dalam penelitian ini dimana memang terjadi kesenjangan antara jumlah barang yang diterima dengan jumlah baranang yang telah dipesan dimana hal tersebut disebabkan oleh mekanisme proses persetujuan pemesanan oleh beberapa pihak yang lama sehingga proses pemesanan dilakukan pada akhir tahun.

\section{KESIMPULAN}

Pada input tidak tergambar faktor penyebab terjadinya kesenjangan antara jumlah obat yang didapatkan dengan jumlah obat yang telah diajukan melalui Rencana Kebutuhan Obat (RKO). Pada proses, penyebab terjadinya kesenjangan antara jumlah obat yang didapatkan dibandingkan dengan obat yang telah diajukan melalui RKO. Pada output tergambar kesenjangan antara jumlah item barang yang diterima dengan item jumlah barang yang dipesan dan belum adanya upaya yang dapat dilakukan untuk menanggulangi permasalahan tersebut.

\section{SARAN}

Dinas Kesehatan Kabupaten Lampung Timur dapat mempercepat proses pengeluaran SK bagi pihakpihak yang terkait dengan proses epurchasing di Puskesmas dan himbauan kepada pihak terkait untuk lebih aktif dalam mengawasi proses e-puchasing sehingga dalam melakukan approve sesegera mungkin untuk efesiensi proses pengadaan obat.

\section{DAFTAR PUSTAKA}

Adyaksa, (2016), Evaluasi Implementasi Pengadaan Obat Berdasarkan Katalog Elektronik (E-Catalogue) di Kota Denpasar Tahun 2015, Skripsi, Program Studi Ilmu Kesehatan Masyarakat, Fakultas Kedokteran Universitas Udayana.

Bottani dan Rizzi, (2005), Strategic management of logistics service: $A$ fuzzy QFD approach, International Journal of Production Economics 103(2):585-599 - February 2006

Dwiaji, dkk., (2016), Evaluasi Pengadaan Obat Publik pada JKN Berdasarkan Data e-Catalogue Tahun 2014-2015, Jurnal ekonomi Kesehatan Indonesia.

Eei et al (2012), Survey on Benefits and Barriers of E-Procurement: Malaysian SMEs Perspective, International Journal on Advanced Science Engineering Information Technology Vol. 2 No. 6 (2012)

Gunasekaran et al. (2008), Adoption of e-procurement in Hong Kong:An empirical research, Int. J. Production Economics 113 (2008) 159-175.

Hermiana, Aida, (2017), Evaluasi Implementasi Pengadaan Obat Berdasarkan Sistem Katalog Elektronik (E-Catalogue) Di Kabupaten Sintang Tahun 2015, Jurnal Ilmiah Ilmu Kefarmasian Vol. 4 No. 2 2017, Program Studi Farmasi Fakultas Kedokteran Universitas Tanjungpura Pontianak.

Kemenkes, (2014), Surat Edaran No 
167 tahun 2014 tentang Pengadaan Obat Berdasarkan Katalog Elektronik (E-Catalogue).

Ketikidis et al., (2010), Applying eprocurement system in the healthcare : the EPOS paradigm. International Journal of Systems Science, 41, 281-299.

Kusmini, (2016), Evaluasi pelaksanaan E-Purchasing Obat pada Dinas Kesehatan kabupaten/Kota Di Jawa Tengah Tahun 2015, Jurnal Kesehatan Vol 6 No. 4 Desember 2016, Fakultas Farmasi Universitas gajah mada Yogyakarta.

Peraturan Presiden No. 16 Tahun 2018 Tentang Pengadaan Barang/Jasa Pemerintah

Permenkes No. 28/2014 Tentang Pedoman Pelaksanaan Program Jaminan Kesehatan Nasional.

Permenkes No. 30/2014 Tentang Standar Pelayanan Kefarmasian di Puskesmas.

Permenkes No. 63/2014 Tentang Pengadaan Obat Berdasarkan Katalog Elektronik(E-Catalogue)

Permenkes No. 21/2016 Tentang Penggunaan Dana Kapitasi Jaminan Kesehatan Nasional untuk Jasa Pelayanan Kesehatan dan Dukungan Biaya Operasional pada FKTP milik Pemerintah Daerah

Sardjo, Darmajanti, \& Boediono, (2016), Implementasi Model Evaluasi Formatif Program Pembangunan Sosial, Jakarta: Pustaka Obor Indonesia.

Sari, (2015), Evaluasi Pemanfaatan Sistem E-Catalogue Terhadap Efektifitas Dan Efisiensi Pengadaan Obat Di Instalasi Farmasi (Studi di Wilayah Gerbangkertasusila), Tesis, Fakultas Farmasi Universitas Airlangga Surabaya.

Suhartini. (2017). Implementasi Kebijakan Pengelolaaan dan Pemanfaatan Dana Kapitasi Jaminan Kesehatan Nasional pada Fasilitas Kesehatan Tingkat
Pertama Milik pemerintah Daerah di Puskesmas Perkotaan Kebupaten Berau, Program Pascasarjana Universitas Terbuka.

Thabrany, H. (2015). Jaminan Kesehatan Nasional (2nd ed.). Depok: PT. Rajagrpindo Persada.

Undang-Undang Nomor 24 Tahun 2011 tentang Badan Penyelenggara Jaminan Sosial (BPJS). 